\title{
Gjesteredaktørens innledning
}

Tatjana Radanović Felberg

Høgskolen i Oslo og Akershus

Tatjana-radanovic.felberg@hioa.no 
Dette temanummeret er en samling artikler som setter kritisk lys på tolking i offentlig sektor i Norge. Det inkluderer både talespråktolking og tegnspråktolking og er et bidrag til kartlegging og utviklingen av det tverrfaglige forskingsfeltet tolking i offentlig sektor. Artiklene er skrevet på norsk (bortsett fra en som er skrevet på dansk) med korte sammendrag på engelsk. Temaene som tas opp bør være av interesse for fagpersoner som jobber i offentlig sektor og kommuniserer via tolk, tolkestudenter, tolker, forskere, tolkeutdannere og andre som er opptatt av kommunikasjon via tolk i offentlig sektor.

Over de siste 30 årene har ulike aspekter ved tolking i offentlig sektor blitt gjenstand for økt interesse, både i Norge og internasjonalt, samtidig som det har oppstått nye problemstillinger rundt profesjonalisering av tolkeyrket, politikken rundt kommunikasjon via tolk $\mathrm{i}$ offentlig sektor og utviklingen av et nytt forskningsfelt. Tolking i offentlig sektor $\mathrm{i}$ Norge defineres som "... bruk av kvalifisert tolk som gjør offentlige tjenesteytere og fagpersoner i stand til å informere, veilede og høre partene på tross av språkbarrierer." (NOU 2014, s. 18). Bruk av tolk er en forutsetning for kommunikasjon når offentlig ansatte og brukere ikke snakker et felles språk. Rundt 300 språk er registrert brukt i Norge i dag, og behov for tolk er rapportert på over 100 språk (NOU 2014, s. 83). I løpet av de siste 40 år har behovet for tolking $\mathrm{i}$ offentlig sektor vokst $\mathrm{i}$ takt med økningen av innvandrere $\mathrm{i}$ Norge. De siste tallene viser at det gjennomføres hundretusenvis av tolkeoppdrag i Norge hvert år (beregning for 2013 er 343000 tolkeoppdrag, NOU 2014: s. 13).

Imidlertid preges fortsatt tolking i offentlig sektor av underforbruk av kvalifiserte tolker og manglende kunnskap om kommunikasjon via tolk blant ansatte $\mathrm{i}$ offentlig sektor (NOU 2014). Selv om det finnes tilbud til utdanning og kvalifisering av tolker og et nasjonalt tolkeregister, er yrket tolk fremdeles i en profesjonaliseringsprosess. Ikke alle som jobber som tolk i Norge har de nødvendige kvalifikasjoner for å utøve profesjonen. Det er ulike grunner til dette, bl.a. henger det sammen med at det ikke er blitt gitt tilbud i utdanning på alle språk og at det ikke kreves kompetansebevis for å arbeide som tolk. De fleste tolkene jobber frilans, og de forskjellige tolkeformidlingstjenestene opererer med ulike kriterier. De ovennevnte momentene tyder på tolkevirksomhetens fortsatt svake profesjonsstatus.

Tolking i offentlig sektor i Norge har blitt viet varierende politisk oppmerksomhet siden 1970-tallet. De siste ti år har det blitt gjort mer for å dokumentere situasjonen i tolking i offentlig sektor (se bl.a. Felberg 2013; Felberg, Calvert \& Ingebricson 2014; IMDi 2007, 2008, 2009, 2011a, 2011b; Linnestad \& Buzungu 2012), og dette løftet kulminerte med NOU-en om tolking i offentlig sektor i 2014. NOU-en understreker tolkingens betydning for rettssikkerhet og likeverd, og det foreslås å utarbeide en egen lov om offentlige myndigheters ansvar for bruk av tolk. Dette er en spennende utvikling som krever en god del arbeid fra alle involverte parter, fra tolkebrukere til politikere.

Tegnspråktolking (mellom norsk og norsk tegnspråk) har en lengre tradisjon i norsk offentlig sektor enn talespråktolking, og profesjonalisering av tegnspråktolking har kommet lengre. Det finnes BA i tegnspråktolking, og tolkene har bedre regulerte arbeidsforhold gjennom NAV som tolkeformidler. Imidlertid var det først i 2008, i og med Stortingsmelding nr. 35 (2007-2008) Mål og mening, at tegnspråktolking ble satt i en større språkpolitisk sammenheng (Vonen 2011, s. 2). Selv om tegnspråktolking og talespråktolking har ulik yrkeshistorikk og de to formene for tolketjeneste er ulikt organisert, handler selve tolkeprosessen om det samme - oversetting fra ett språk til et annet, og de to feltene utfordres av lignende tolkeetiske problemstillinger. Et eksempel på felles tolkeetiske problemstillinger er kommunikasjonsdeltakeres ulike forståelser av tolkens funksjon. Denne problemstillingen er tett knyttet til både den politiske og den allmenne forståelsen av de gruppene tolken jobber for. Oppfatter man døve som minoritet eller som funksjonshemmede? Oppfatter man innvandrere som minoriteter eller som trengende? 
Forskning om tolking i offentlig sektor er av nyere dato og har foregått innen forskjellige fagfelt. Dette gjør det vanskelig å ha en helhetlig oversikt over alt som er blitt gjort i Norge. Dette temanummeret er et forsøk på å føre sammen forskere med ulik bakgrunn og erfaring og med tilhørighet til ulike fagtradisjoner. Artiklene viser at tverrfaglige tilnærminger står sentralt hos alle. Artikkelforfatterne kombinerer og bruker elementer fra språkvitenskap, sosiologi, antropologi, filosofi og psykologi. De bruker også ulike metoder i sin forskning: fra diskursanalyse av dokumenter, spørreundersøkelser, dybdeintervjuer og fokusgrupper blant tolker og tolkebrukere, til beskrivelse av tolking i autentiske situasjoner. Flere av artiklene bruker autentiske data fra offentlig sektor i Norge. Dette viser en tett forbindelse mellom forskning og praksis. Forskerne kommer med eksempler fra ulike kontekster: helsevesen, rettsvesen (politi, UDI) og ulike arbeidsplasser.

Artikkelforfatterne er opptatt av temaer som strekker seg fra det generelle, som drøfting av profesjonalisering av tolking og ulike forståelser av tolkens funksjon, til mer spesifikke problemstillinger som hvordan tolker og tolkebrukere kan forbedre sine ferdigheter.

"Rettstolking og rettssikkerhet i et norsk perspektiv" av Åse Johnsen gir en kritisk gjennomgang av status for tolking $\mathrm{i}$ retten $\mathrm{i}$ Norge. Til tross for at det har skjedd forbedringer i tolking i norske rettssaler, trues fortsatt rettsikkerheten av tolkens og tolkebrukerens manglende kompetanse og forståelse for tolkeyrket. Artikkelen setter søkelyset på profesjonaliseringsprosessen av tolkeyrket gjennom en analyse av autentiske eksempler fra opptak av tolking fra tingretten i Bergen og undersøkelser gjort blant tolker som er registrert i tolkeregisteret. Artikkelforfatteren hevder at tolkeregisteret er med på å undergrave den gryende profesjonalisering av tolkeyrket i Norge ved a legitimere bruk av ukvalifiserte personer som tolker i norske rettssaler, og hun legger fram et forslag til hvordan tolkeregisterets kategorisering kan endres.

I artikkelen "Når trenger jeg å tilkalle tolk? Forskning om tolking i helsetjenesten" av Gry Sagli går vi fra rettskontekst til helsekontekst. Sagli gir en oversikt over forsking om tolking i helsevesenet i Norge med utgangpunkt i det viktige spørsmålet: Når trenger jeg å tilkalle tolk? Hun viser særlig til to viktige forhold som bør bli bedre undersøkt i framtiden, nemlig sammenhengen mellom pasientens ferdighetsnivå i norsk og behov for tolk, og hvordan behovet for tolk i helsetjenesten graderes etter en oppfatning om hvor viktig samtalen er.

I "Tegnspråktolking, profesjon i diskursiv klem" tar Ingeborg Skaten utgangpunkt i at hver profesjon, inkludert tolkens, er en sosial konstruksjon. Denne forståelsen innebærer at profesjoner kan endres over tid og sted. Målet til forfatteren er å identifisere og analysere hvilke diskurser om tegnspråktolking som eksisterer i Norge. Skaten hevder at kritisk lesning av sentrale tekster om tegnspråktolking avdekker en tvetydig posisjon for tolken og profesjonen. På den ene siden eksisterer konstruksjonen av tolking som velferdsgode, og på den andre konstruksjonen av tolking som profesjon. Dette er avhengig av hvordan man forstår døve - som funksjonshemmede eller som språklig minoritet. Gjennom sin analyse viser forfatteren at rapporten Fornying av tolketjenesten utgitt av NAV kan forstås som et forslag til en utvidelse av tolkens rolle, og hun setter kritiske spørsmål ved den.

Gro Hege Saltnes Urdal bidrar med artikkelen "Tillit og kvalitet"og tar utgangpunkt i et sosialkonstruksjonistisk perspektiv når hun ser etter svar på hva god kvalitet i tolking er. Hun har stilt følgende spørsmål til to fokusgrupper, en bestående av døve tolkebrukere og en bestående av tegnspråktolker: Hva må til for å legge til rette for god kommunikasjon og dermed god kvalitet på tolkingen? Resultatet fra fokusgruppeintervjuer viser at tillit og kvalitet er knyttet sammen. Tillit opparbeides på ulike måter hos døve og hos tolker. Dersom døve tolkebrukere opplever tolkingen som god, fører det til tillit til tolken. Tolkene på sin side er avhengige av tillit for å kunne yte best mulig i situasjonen. Åpenhet rundt denne ulikheten er et godt utgangspunkt for samarbeid, mener forfatteren. En 
forventningsavklaring og gode samarbeidsrutiner kan bidra til at begge parter føler seg trygge.

Sarah Evans-Jordans artikkel " $\AA$ være til stede på en god måte: Tegnspråktolkers refleksjoner rundt å jobbe i Tolk på arbeidsplassordningen (TPA)" bygger på undersøkelsen artikkelforfatteren utførte i forbindelse med sin MA-oppgave. Hun tar utgangpunkt i kvalitative intervjuer med tegnspråktolker som jobber i TPA. Ordningen betyr at tolker er knyttet til en arbeidsplass og ikke blir tilkalt tilfeldig til forskjellige arbeidsplasser. Tolkene evaluerer TPA som en ordning som gir dem rom for å utøve sin jobb på en bedre måte. Ved økt tilstedeværelse på ett arbeidssted blir tolkenes språkføring bedre, og de blir bedre kjent med brukerne. Imidlertid uttrykte tolkene at de opplevde etiske utfordringer som oppstår som et resultat av spenning mellom praksis og de etiske retningslinjene.

Elisabet Tiselius analyserer tolkeutdanninger i Norge i artikkelen "Hva trenger tolkestudenten for å lære?" og diskuterer ulike pedagogiske tilnærminger som er i bruk. Tolkestudenter i Norge er i hovedsak voksne personer og en sammensatt gruppe når det gjelder kjønn, alder, språk, yrke og etnisitet. De fleste tolkestudentene jobber allerede som tolk. Dette mangfoldet representerer både en ressurs og en utfordring for tolkeutdannere, mener Tiselius. Hun foreslår en blanding av pedagogiske og metodologiske perspektiver som critical incident technique, constructive alignment og experiential learning som et bidrag til styrking av tolkeutdanning.

Med utgangspunkt i en praktisk problemstilling om bruk av tid i gjennomlesing av asylintervjuer i Utlendingsdirektoretat beskriver Tatjana R. Felbergs artikkel "Utfordringer ved prima vista tolking i asylintervjuer" omstendighetene rundt intervjusituasjonen og bekrefter at oppgaven utføres på ulike måter av ulike tolker $\mathrm{i}$ ulike tolkesituasjoner. Imidlertid ligger ikke grunnen til dette bare i tolkens kunnskaper og ferdigheter, men også hos de andre kommunikasjonsdeltakerne og i selve konteksten for asylintervjuet. Med utgangpunkt $\mathrm{i}$ analyse av både asylintervjuer og UDI-tolkers synspunkter konkluderer artikkelforfatteren med at asylintervjuet er et resultat av samhandling mellom alle personene som er til stede. Dette betyr at bruk av tiden som går med til gjennomlesing av asylintervjuer ikke kan forkortes uten å se på hele tolkesituasjonen. Felberg foreslår at både tolker og intervjuere bør få en grunnleggende innføring i hovedutfordringene med prima vista tolking, og hun skisserer mulige løsninger for å forbedre det profesjonelle samarbeidet mellom saksbehandlere og tolker i UDI.

\section{Pedagogisk utviklingsarbeid}

I artikkelen "Tolking i forbindelse med politiafhøring. Problemer og mulige løsninger" tar Kristina Kepinska Jakobsen utgangpunkt i tolkebrukere og beskriver politietterforskernes utfordringer i avhør via tolk. Det ser ut som om forhold ved den avhørsmodellen som brukes i Norge (KREATIV) som innebærer utstrakt bruk av fri forklaring, bidrar til utfordringer. Under sitt arbeid med utvikling av avhørsstudier på Politihøgskolen i Oslo har artikkelforfatteren fătt tilbakemeldinger fra politiansatte som viser at utfordringene, i tillegg til å handle om avhørsteknikker, også kan ligge i tolkens og tolkebrukernes (mangel på) kompetanse, kontaktoppnåelse med den avhørte og kulturelle faktorer. Som løsning på disse utfordringene foreslås det utdanning både av tolker og tolkebrukere (her politiansatte) og felles moduler hvor politiansatte og tolkestudenter øver sammen.

Et annet viktig tema innen pedagogisk utviklingsarbeid handler om tolkens egen helse. Daniela Feistritzer viser i "Traumatiske reaksjoner hos tolker i offentlig sektor" hvordan traumatiske reaksjoner hos tolken kan påvirke tolkingen. Hun hevder at i motsetning til andre yrkesgrupper som er eksponert til traumatiske historier, som for eksempel psykologer, sykepleiere og sosialarbeidere, er ikke tolker forberedt i sin utdanning til å 
håndtere slike situasjoner. Artikkelen analyserer tolkenes egne refleksjoner om dette temaet og peker på viktigheten av å integrere det i tolkeutdanningen.

I sitt studentessay "Fra hjelper til profesjonsutøver - profesjonalisering av tolkeyrket $\mathrm{i}$ Norge" viser Hanne Kristine Angelshaug problemstillinger sett fra studentens/den praktiserende tolkens ståsted. Hun setter kritisk lys på forskjellen mellom ufaglærte og utdannete tolker og betydningen dette har for profesjonalisering av tolking i Norge. I motsetning til Johansen mener Angelshaug at tolkeregisteret som er det første skillet mellom ufaglært og utdannet tolk, noen ganger kan komme til å ekskludere godt kvalifiserte tolker. Hun mener årsaken ligger $\mathrm{i}$ et begrenset tilbud både om autorisasjon og utdanning $\mathrm{i}$ tolking av alle de språkene det er behov for i Norge. På den andre siden viser Angelshaug at de offentlig ansatte har problemer med å skille mellom ufaglærte og utdannede tolker $\mathrm{i}$ offentlig sektor. Som løsning på disse problemene foreslår hun bl.a. bruk av tolkeregisteret som et absolutt krav når man skal kjøpe tolketjenester, større tilgang til utdanning og at IMDi, som er fagmyndighet på området tolking i offentlig sektor, må bidra sterkere til profesjonaliseringen av tolkene.

Til slutt har Kristina Solum anmeldt et meget viktig bidrag til fagfeltet, Den topartiske tolken, lærebok i tolking av Hanne Skaaden som kom ut i 2013. 


\section{Referanser}

Felberg, T. R., Calvert, S. \& Ingebricson E. (Regissører). (2014). Et bidrag til historien om tolking i offentlig sektor i Norge. HiOA. Hentet fra

Del 1: https://vimeo.com/113284255;

Del 2: https://vimeo.com/113284257;

Del 3 https://vimeo.com/113284256

Felberg, T. R. (2013). Kommunikasjon via tolk for offentlig ansatte (Rapport 2013/07). Oslo: Høgskolen i Oslo og Akershus. Hentet fra

http://www.hioa.no/Studier/LU/Evu/kommunikasjonviatolk/Rapport-kommunikasjon-

IMDi - Integrerings- og mangfoldsdirektoratet. (2007). Fastleger og tolketjenester (IMDirapport nr. 6/2007). Hentet fra http://www.tolkeportalen.no/Global/tolking/Tolkeportalen/62007nettTolk.pdf

IMDi - Integrerings- og mangfoldsdirektoratet. (2008). Bruk av tolk i barnevernet (IMDirapport nr. 5/2008). Hentet fra http://www.tolkeportalen.no/Global/IMDi-rapport\%205-2008tolkibv.pdf

IMDi - Integrerings- og mangfoldsdirektoratet. (2009). Bruk av tolk i straffesakskjeden (IMDi-rapport nr. 6/2009). Hentet fra http://www.tolkeportalen.no/Documents/IMDi-rapport6-2009tolknett.pdf

IMDi - Integrerings- og mangfoldsdirektoratet. (2011a). "Mora mi forstår ikke når lærerne snakker", Bruk av tolk i grunnskolen i Oslo. (IMDi-rapport nr. 2/2011). Hentet fra http://www.tolkeportalen.no/Documents/Rapporter/Tolk_Oslo-skolen.pdf

IMDi - Integrerings- og mangfoldsdirektoratet. (2011b). Rett til informasjon ved språkbarriere. Bruk av tolk i Arbeids- og velferdsforvaltningen (NAV). (IMDi-rapport nr. 3/2011). Hentet fra http://www.tolkeportalen.no/Documents/Rapporter/Bruk av tolk i NAV.pdf

Linnestad, H., \& Buzungu, H. F. (2012). Ikke lenger en tjeneste av ukjent kvalitet: Statusrapport om tolkefeltet $i$ helsevesenet $i$ hovedstadsomradet, Oslo universitetets sykehus (Rapport 15 juni 2012/rev. 15 mai 2013). Oslo: Helse Sør-Øst og Oslo Kommune.

NOU nr. 8 (2014) Tolking i offentlig sektor- at spørsmål om rettssikkerhet og likeverd Oslo: Barne-, likestilings, og inkluderingsdepartementet. Hentet fra https://www.regjeringen.no/nb/dokumenter/NOU-2014-8/id2001246/

Vonen, A. (2011) Tegnspråk og statlig språkpolitikk i Statsspråk, bladet for godt språk i staten nr. 4, s. 2. 